\title{
PENERAPAN PEMBELAJARAN KOOPERATIF TEKNIK DUA TINGGAL DUA TAMU DENGAN MENGGUNAKAN LKS PADA PEMBELAJARAN MATEMATIKA SISWA KELAS X SMAN 1 LEMBAH GUMANTI
}

\author{
Nurlev Avana \\ STKIP Muhammadiyah Muara Bungo, Jambi \\ nurlevavana@yahoo.com
}

\begin{abstract}
The ability of understanding mathematical concepts and communication skills was a math learning goals stated by the Ministry of Education, and was a very important aspect in learning mathematics. Lack of communication skills and understanding of mathematical concepts students will affect the quality of student learning that result in low student achievement in school, it was also happening in SMA N Lembah Gumanti. Coperative tipe two stay two stray was one alternative to improve the liveliness and creativity of students in learning. This research is a Quasi Experiment. The population in this study were students of SMA N Lembah Gumanti District. The samples in this study were students of class X3 SMAN 1 Lembah Gumanti as experimental class and X4 SMAN 1 grade students as a class randomly selected controls. Instrument used was a written test. The data obtained were analyzed using test mann-whitney $u$. The results showed that the ability of understanding the overall concept and capable students who are taught by low initial learning activen learning higher than students taught with conventional learning, communication skills and capable overall high initial learning strategies Coperative tipe two stay two stray higher than the students who taught by conventional learning.
\end{abstract}

Keywords : Cooperative Learning Technique Two Stay Two Guests

\begin{abstract}
Abstrak
Kemampuan memahami konsep matematika dan keterampilan komunikasi merupakan tujuan pembelajaran matematika yang dinyatakan oleh Departemen Pendidikan, dan merupakan aspek yang sangat penting dalam pembelajaran matematika. Kurangnya keterampilan komunikasi dan pemahaman konsep matematika siswa akan mempengaruhi kualitas belajar siswa yang mengakibatkan rendahnya prestasi belajar siswa di sekolah, hal itu juga terjadi di SMA N Lembah Gumanti. Koperatif tipe two stay two stray adalah salah satu alternatif untuk meningkatkan keaktifan dan kreativitas siswa dalam belajar. Penelitian ini adalah Eksperimen Kuasi. Populasi dalam penelitian ini adalah siswa SMA Negeri N Lembah Gumanti. Sampel dalam penelitian ini adalah siswa kelas X3 SMAN 1 Lembah Gumanti sebagai kelas eksperimen dan siswa kelas X4 SMAN 1 sebagai kelas kontrol yang dipilih secara acak. Instrumen yang digunakan adalah tes tertulis. Data yang diperoleh dianalisis menggunakan uji u. Hasil penelitian menunjukkan bahwa kemampuan memahami konsep keseluruhan dan kemampuan siswa yang diajar dengan pembelajaran awal rendah mengaktifkan pembelajaran lebih tinggi daripada siswa yang diajarkan dengan pembelajaran konvensional, keterampilan komunikasi dan keseluruhan strategi pembelajaran awal yang mampu tinggi. yang diajar dengan pembelajaran konvensional.
\end{abstract}

Kata Kunci: Pembelajaran Kooperatif Teknik Dua Tinggal Dua Tamu

\section{PENDAHULUAN}

Matematika merupakan sarana berpikir ilmiah yang dapat mempercepat pemahaman ilmu eksakta, teknik, sosial dan juga disiplin ilmu lainnya. Hal ini dipertegas oleh Suherman (2003) bahwa matematika adalah sarana untuk berpikir, matematika adalah logika pada masa dewasa, matematika adalah ratunya ilmu dan sekaligus pelayannya. Matematika adalah sains mengenai kuantitas dan besaran, matematika adalah sains formal yang murni, matematika adalah sains yang memanipulasi simbol, matematika adalah ilmu yang mempelajari hubungan pola, bentuk dan struktur.

Berdasarkan hasil observasi penulis di kelas X SMA Negeri 1 Lembah Gumanti, Pada umumnya siswa tidak mempersiapkan diri sebelum belajar. Tugas yang diberikan tidak dikerjakan dan siswa masih 
malas untuk bertanya kepada guru. Karena kurangnya persiapan siswa dan tidak terlibatnya siswa dalam pembelajaran, berakibat kurang baik terhadap proses pembelajaran. Hal ini akhirnya berpegaruh terhadap rendahnya hasil ujian MID semester II matematika siswa kelas X SMA N 1 Lembah Gumanti

Dari uraian di atas, maka perlu dicarikan solusi untuk mengatasi permasalahan tersebut sehingga pembelajaran matematika menjadi bermakna, mampu mengembangkan kemampuan matematis siswa serta pembelajaran tidak lagi terpusat pada guru. Diantara metode atau model pembelajaran yang dapat digunakan untuk mengatasi masalah tersebut diatas seperti: Pembelajaran Kooperatif, model pembelajaran aktif, dll, dari beberapa model atau metode tersebut metode pembelajaran kooperatif diduga bisa mengatasi masalah tentang tentang hasil belajar matematis siswa.

Ibrahim (2000) menjelaskan ciri-ciri pembelajaran kooperatif sebagai berikut.

1) Siswa bekerja dalam kelompok secara kooperatif untuk menuntaskan materi belajarnya.

2) Kelompok dibentuk dari siswa yang memiliki kemampuan tinggi, sedang dan rendah.

3) Bilamana mungkin, anggota kelompok berasal dari ras, budaya, suku, jenis kelamin yang berbeda.

Model pembelajaran Kooperatif memiliki banyak tipe, diantara tipe tersebut yaitu dua tinggal dua tamu atau two stay two stray (TSTS) dimana tipe ini dikembangkan oleh Spencer Kagan yaitu pada tahun 1992. Model pembelajaran kooperatif tipe TSTS merupakan model pembelajaran yang struktur TSTS memberi kesempatan kepada kelompok untuk membagikan hasil dan informasi dengan kelompok lain, Anita Lie (2008).

Dalam model pembelajaran kooperatif tipe TSTS ini memiliki tujuan yaitu siswa diajak untuk bergotong royong dalam menemukan suatu konsep. Penggunaan model pembelajaran kooperatif TSTS akan mengarahkan siswa untuk aktif, baik dalam berdiskusi, tanya jawab, mencari jawaban, menjelaskan dan juga menyimak materi yang dijelaskan oleh teman. Selain itu, alasan menggunakan model pembelajaran tipe TSTS ini karena terdapat pembagian kerja kelompok yang jelas tiap anggota kelompok, siswa dapat bekerjasama dengan temannya, dapat mengatasi kondisi siswa yang ramai dan sulit diatur saat proses belajar mengajar, Istarani (2012).

Menurut Istarani (2012), terdapat beberapa kelebihan dari model pembelajaran kooperatif tipe TSTS, model ini sangat cocok digunakan dalam rangka meningkatkan:

1) Kerja sama didalam kelompok maupun diluar kelompok dalam proses belajar mengajar.

2) Kemampuan siswa dalam memberikan informasi kepada temannya yang lain diluar kelompok dan begitu juga sebaliknya ketika siswa lain balik ke dalam kelompoknya masing-masing.

3) Kemampuan siswa dalam menyatukan ide dan gagasannya terhadap materi yang dibahasnya dalam kelompok maupun ketika menyampaikan kepada siswa yang diluar kelompoknya.

4) Keberanian siswa dalam menyampaikan bahan ajar pada temannya.

5) Melatih siswa untuk berbagi terutama berbagi ilmu pengetahuan yang didapatnya dalam kelompok.

6) Pembelajaran akan tidak membosankan, sebab antara siswa selalu berinteraksi dalam kelompok maupun di luar kelompok.

7) Melatih kemandirian siswa dalam belajar.

Sehubungan dengan pendapat Istarani (2012) adapun kelemahan dari model pembelajaran kooperatif tipe TSTS adalah sebagai berikut :

1) Dapat mengundang keributan ketika siswa bertamu ke kelompok lain.

2) Siswa yang kurang aktif akan kesulitan mengikuti proses pembelajaran seperti ini.

3) Pembelajaran kurang mendalam, sebab sepenuhnya diserahkan pada siswa tanpa ada penjelasan materi sebelumnya.

4) Model seperti ini adakalanya penggunaan waktu yang kurang efektif. 
Proses pembelajaran dengan menggunakan model ini menuntut siswa untuk bekerja bersama dan mengemukakan pendapatnya berdasarkan hasil yang diperolehnya dalam mengidentifikasi unsur-unsur intrinsik pada cerpen. Model pembelajaran ini mampu membantu siswa yang lemah dan kurang aktif menjadi aktif dalam mengutarakan pendapat dari kelompok ke kelompok lainnya

Berdasarkan langkah-langkah di atas, maka langkah-langkah model pembelajaran kooperatif teknik DTDT dalam proses pembelajaran pada penelitian adalah:

1) Siswa duduk di kelompok masing-masing.

2) Masing-masing kelompok mengutus dua orang temannya bertamu ke kelompok lain untuk mencocokkan dan mendiskusikan hasil pekerjaannya, yang pergi bertamu mempunyai kemampuan tinggi dan rendah. sementara dua anggota yang tinggal memberikan informasi kepada tamunya.

3) Tamu mohon diri dan kembali ke kelompok masing-masing dulu.

4) Selanjutnya dua siswa yang tinggal pergi lagi bertamu ke kelompok lain yaitu yang mempunyai kemampuan sama-sama sedang.

5) Kelompok kembali dan baru membahas hasil temuannya dari kelompok lain.

Jadi dalam pembelajaran dengan menggunakan teknik ini siswa dilatih untuk aktif dan memiliki rasa tanggung jawab yang besar terhadap diri sendiri dan orang lain.

LKS yang baik akan memberi keseragaman pandangan siswa terhadap pengamatan dalam menanamkan konsep yang benar dengan program yang telah diatur sedemikian rupa sehingga dapat mengatasi kesukaran yang mungkin timbul selama proses pembelajaran berlangsung.

Berdasarkan uraian tersebut, maka dalam penelitian ini yang penulis teliti adalah ranah kognitif yaitu hasil belajar berupa nilai matematika siswa setelah mengalami proses pembelajaran kooperatif teknik Dua Tinggal Dua Tamu. Pembelajaran konvensional adalah pembelajaran yang berpusat pada guru, dimana guru bertindak secara aktif sedangkan murid bertindak secara pasif. Sebagaimana yang dikemukakan oleh Djafar (2001) bahwa: Strategi pembelajaran konvensional merupakan pembelajaran yang berorientasi pada guru atau lembaga pendidikan, dalam arti seluruh keputusan operasional diarahkan untuk dan bagaimana cara lembaga pendidikan dan peranan guru dalam mengorganisir pembelajaran.

\section{METODE PENELITIAN}

Pelitian ini dilaksanakan dengan menggunakan metode kuasi eksperimen dengan pendekatan kuantitatif. Terdapat dua kelompok sampel pada penelitian ini yaitu kelompok eksperimen yang dilaksanakan dengan menggunakan model pembelajaran kooperatif teknik Dua Tinggal Dua Tamu dan kelompok control dengan pembelajaran konvensional. M. Nazir (2003) mengemukakan bahwa penelitian eksperimen adalah penelitian yang dilakukan dengan mengadakan manipulasi terhadap objek penelitian serta adanya kontrol.

Rancangan yang digunakan dalam penelitian ini untuk melihat pengaruh penggunaan model pembelajaran kooperatif teknik Dua Tinggal Dua Tamu terhadap kemampuan matematis siswa adalah Randomized Group Pretest-Posttest Design yang digambarkan sebagai berikut:

Tabel 1 : Desain Penelitian

\begin{tabular}{cccc}
\hline & Pre-test & Perlakuan & Posttest \\
\hline Eksperimen & $\mathrm{T}$ & $\mathrm{X}_{1}$ & $\mathrm{~T}$ \\
Kontrol & $\mathrm{T}$ & $\mathrm{X}_{2}$ & $\mathrm{~T}$ \\
\hline
\end{tabular}

Keterangan :

$\mathrm{X}_{1}=$ Perlakuan pada kelas eksperimen yaitu mengunakan model pembelajaran kooperatif teknik Dua Tinggal Dua Tamu

$\mathrm{X}_{2}=$ Perlakuan pada kelas control, yaitu pembelajaran konvensional

$\mathrm{T}=$ Pre-test $=$ Posttest 
Rancangan tersebut diterapkan pada situasi belajar yang berbeda yakni dengan menggunakan Model pembelajaran kooperatif teknik Dua Tinggal Dua Tamu pada kelas eksperimen dan pembelajaran konvensional pada kelas control. Rancangan penelitian tersebut digambarkan dalam tabel 4 berikut:

Tabel 2 : Tabel Anova Design Faktorial Interaksi 2 x 2

\begin{tabular}{|c|c|c|}
\hline $\mathrm{C}_{\text {Kemampuan Awal }}$ Pembelajaran & $\begin{array}{c}\text { Model Pembelajaran } \\
\text { Kooperatif teknik Dua } \\
\text { Tinggal Dua Tamu } \\
\text { (A) }\end{array}$ & $\begin{array}{c}\text { Konvensional } \\
(\mathrm{K})\end{array}$ \\
\hline Kemampuan awal tinggi (HT) & HTA & HTK \\
\hline Kemampuan awal rendah (HR) & HRA & HRK \\
\hline
\end{tabular}

\section{Keterangan:}

HTA : Hasil belajar matematik siswa dengan kemampuan awal tinggi yang mengikuti pembelajaran dengan menggunakan model pembelajaran kooperatif teknik Dua Tinggal Dua Tamu

HTK : Hasil belajar matematik siswa dengan kemampuan awal tinggi yang mengikuti pembelajaran dengan pendekatan konvensional

HRA : Hasil belajar matematik siswa dengan kemampuan awal rendah yang mengikuti pembelajaran dengan menggunakan model pembelajaran kooperatif teknik Dua Tinggal Dua Tamu

HRK : Hasil belajar matematiksiswa dengan kemampuan awal rendah yang mengikuti pembelajaran dengan pendekatan konvensional

Sebelum dilakukan penelitian, maka terlebih dahulu ditentukan populasi penelitian. Populasi dalam penelitian ini adalah sebagian siswa kelas X SMAN 1 Lembah Gumanti. Sampel adalah bagian dari populasi yang mana harus representatif. Artinya segala karakteristik populasi tercermin dalam sampel yang diambil. Sudjana (2005) menyatakan bahwa: "Sampel penelitian adalah sebagian populasi yang memiliki sifat dan karakter yang sama sehingga betul-betul mewakili populasinya". Mengingat jumlah populasi yang sangat besar dan terbatasnya kemampuan penulis maka penelitian dilakukan terhadap sampel yang mewakili populasi.

Berdasarkan metode penelitian yang digunakan, maka dipilih dua kelas sampel sebagai kelas eksperimen dan kelas kontrol. Untuk menentukan sampel pada penelitian ini digunakan teknik Random Sampling. Sampel yang dipilih haruslah sampel yang representative sehingga menggambarkan keseluruhan karakteristik dari suatu populasi. langkah-langkah yaitu: 1). Mengumpulkan data nilai ulangan mid semester 1 siswa kelas populasi. 2). Melakukan uji kesamaan rata-rata. 3). Untuk menentukan jenis uji kesamaan rata-rata yang digunakan, terlebih dahulu dilakukan uji normalitas dan uji homogenitas variansi. Uji normalitas bertujuan untuk mengetahui apakah kelas populasi berdistribusi normal atau tidak. Uji homogenitas variansi, bertujuan untuk mengetahui apakah kelas populasi mempunyai variansi yang homogen atau tidak.

Teknik serta prosedur yang digunakan dalam pengumpulan data pada penelitian ini yaitu sebagai berikut :

1) Memberikan tes kemampuan awal kepada siswa kelas eksperimen dan kelas kontrol. Sebelum soal diberikan kepada siswa, terlebih dahulu soal divalidasi oleh validator kemudian diuji cobakan. Soal tes kemampuan awal yang diberikan yaitu berupa tes essay mengenai materi prasyarat materi berikutnya. Kemudian mengelompokkan siswa berdasarkan kemampuan awal tinggi, dan rendah. 
2) Memberikan tes akhir belajar pada kelas eksperimen dan kontrol setelah diberikan perlakuan. Soal-soalnya berisi soal kemampuan matematis. Tes ini berbentuk essay yang dirancang sesuai dengan indikator kemampuan matematis siswa. Sebelum soal ini diberikan kepada siswa, terlebih dahulu soal ini diuji cobakan pada kelas yang sama karakteristiknya dengan sampel penelitian.

Teknik analisis data dilakukan dengan tujuan untuk melihat apakah rata-rata skor hasil belajar antara kelas eksperimen berbeda dengan kelas kontrol. Untuk melakukan uji statistik maka terlebih dahulu dilakukan uji normalitas, uji homogenitas variansi kedua kelompok data.

1) Uji Normalitas. Uji normalitas bertujuan untuk melihat apakah data berdistribusi normal atau tidak. Uji normalitas dapat dilakukan dengan menggunakan Kolmogrof - Smirnov, uji ini dilakukan dengan menggunakan Software SPSS. Data berdistribusi normal jika nilai signifikansinya lebih besar dari taraf nyata yaitu 0,05 dengan hipotesis sebagai berikut :

$\mathrm{H}_{0}$ : Data berdistribusi normal

$\mathrm{H}_{1}$ : Data tidak berdistribusi normal

2) Uji Homogenitas. Uji homogenitas variansi digunakan untuk menguji kesamaan variansi pada kedua sampel (kelas kontrol dan kelas eksperimen) pada kemampuan matematis siswa. Uji ini dilakukan dengan menggunakan uji Levene dengan bantuan SPSS kriteria pengujian adalah sampel memili variansi yang homogen jika sig > taraf nyata yaitu 5\%. Dengan hipotesis statistik sebagai berikut :

$\mathrm{H}_{0}: \sigma_{1}{ }^{2}=\sigma_{2}{ }^{2}$

$\mathrm{H}_{1}: \sigma_{1}{ }^{2} \neq \sigma_{2}^{2}$

3) Uji Hipotesis. Uji hipotesis bertujuan untuk mengetahui apakah terdapat perbedaan hasil belajar atau kemampuan matematis siswa kelas eksperimen dan kelas kontrol

$\begin{array}{llll}\text { Hipotesis 1 } & \mathrm{H}_{0}: \mu \mathrm{M}_{11} & =\mu \mathrm{M}_{21} \\ & \mathrm{H}_{1} & : \mu \mathrm{M}_{11} & >\mu \mathrm{M}_{21} \\ \text { Hipotesis 2 } & \mathrm{H}_{0} & : \mu \mathrm{K}_{\mathrm{t}} \mathrm{M}_{11} & =\mu \mathrm{K}_{\mathrm{t}} \mathrm{M}_{21} \\ & \mathrm{H}_{1} & : \mu \mathrm{K}_{\mathrm{t}} \mathrm{M}_{11} & >\mu \mathrm{K}_{\mathrm{t}} \mathrm{M}_{21} \\ \text { Hipotesis 3 } & \mathrm{H}_{0}: \mu \mathrm{K}_{\mathrm{s}} \mathrm{M}_{11}=\mu \mathrm{K}_{\mathrm{s}} \mathrm{M}_{21} \\ & \mathrm{H}_{1}: \mu \mathrm{K}_{\mathrm{s}} \mathrm{M}_{11}>\mu \mathrm{K}_{\mathrm{s}} \mathrm{M}_{21} \\ \text { Hipotesis 4 } & \mathrm{H}_{0}: \mu \mathrm{K}_{\mathrm{r}} \mathrm{M}_{11}=\mu \mathrm{K}_{\mathrm{s}} \mathrm{M}_{21} \\ & \mathrm{H}_{1}: \mu \mathrm{K}_{\mathrm{r}} \mathrm{M}_{11}>\mu \mathrm{K}_{\mathrm{s}} \mathrm{M}_{21} \\ \text { Hipotesis 5 } & \mathrm{H}_{0}: \mu \mathrm{M}_{12}=\mu \mathrm{M}_{22} \\ & \mathrm{H}_{1}: \mu \mathrm{M}_{12}>\mu \mathrm{M}_{22} \\ \text { Hipotesis 6 } & \mathrm{H}_{0}: \mu \mathrm{K}_{\mathrm{t}} \mathrm{M}_{12}=\mu \mathrm{K}_{\mathrm{t}} \mathrm{M}_{22} \\ & \mathrm{H}_{1}: \mu \mathrm{K}_{\mathrm{t}} \mathrm{M}_{12}>\mu \mathrm{K}_{\mathrm{t}} \mathrm{M}_{22} \\ \text { Hipotesis 7 } & \mathrm{H}_{0}: \mu \mathrm{K}_{\mathrm{s}} \mathrm{M}_{12}=\mu \mathrm{K}_{\mathrm{s}} \mathrm{M}_{22} \\ & \mathrm{H}_{1}: \mu \mathrm{K}_{\mathrm{s}} \mathrm{M}_{12}>\mu \mathrm{K}_{\mathrm{s}} \mathrm{M}_{22} \\ \text { Hipotesis 8 } & \mathrm{H}_{0}: \mu \mathrm{K}_{\mathrm{r}} \mathrm{M}_{12}=\mu \mathrm{K}_{\mathrm{s}} \mathrm{M}_{22} \\ & \mathrm{H}_{1}: \mu \mathrm{K}_{\mathrm{r}} \mathrm{M}_{12}>\mu \mathrm{K}_{\mathrm{s}} \mathrm{M}_{22}\end{array}$

Hipotesis $9 \& \quad \mathrm{H}_{0} \quad: \quad \mu \mathrm{K}_{\mathrm{t}} \mathrm{M}_{1}=\mu \mathrm{K}_{\mathrm{t}} \mathrm{M}_{2}=\mu \mathrm{K}_{\mathrm{s}} \mathrm{M}_{1}=\mu \mathrm{K}_{\mathrm{s}} \mathrm{M}_{2}=\mu \mathrm{K}_{\mathrm{r}} \mathrm{M}_{1}=\mu \mathrm{K}_{\mathrm{r}} \mathrm{M}_{2}$

Hipotesis 10

$\mathrm{H}_{1}$ : Terdapat interaksi antara model pembelajaran dengan kemampuan awal siswa terhadap kemampuan pemahaman konsep dan kemampuan pemecahan masalah matematis siswa

Untuk pengujian hipotesis 1, 2, 3, 4, 6, 7 dan 8 dilakukan dengan menggunakan Uji-t jika data berdistribusi normal dan mempunyai variansi yang homogen, menggunakan Uji-t' jika data berdistribusi normal dan mempunyai variansi yang tidak homogen dan menggunakan uji Mann-Whitney $U$ jika data 
tidak berdistribusi normal. Dalam penelitian ini uji hipotesis dilakukan dengan bantuan software SPSS. Kriteria pengujiannya adalah tolak $\mathrm{H}_{0}$ jika nilai Sig. $<$ taraf nyata $(\alpha=0,05)$ dan terima $\mathrm{H}_{0}$ jika sebaliknya.

Hipotesis 9 dan 10 akan diuji menggunakan Anava Dua Arah. Dalam penelitian ini Anava digunakan untuk menguji ada tidaknya interaksi antara model pembelajaran dan kemampuan awal terhadap pemahaman konsep dan kemampuan komunikasi matematis

\section{HASIL DAN PEMBAHASAN}

Data hasil belajar siswa diperoleh setelah tes hasil belajar dilaksanakan pada kedua kelas sampel. Siswa yang mengikuti tes akhir pada kedua kelas sampel terdiri dari 38 orang siswa pada kelas eksperimen dan 38 orang siswa pada kelas kontrol. Seorang siswa dikatakan tuntas belajar jika telah menguasai $55 \%$ dari materi pelajaran. Suatu kelas dikatakan telah tuntas dalam belajar jika $85 \%$ dari siswa dalam kelas itu telah tuntas belajar. Skor maksimum siswa jika menjawab dengan benar seluruh yang diujikan adalah 100 .

Uji perbedaan rata-rata bertujuan untuk melihat apakah terdapat perbedaan hasil belajar siswa dari kedua kelompok sampel tersebut. Untuk menguji hipotesis digunakan uji t-test dengan hipotesis

Harga $t_{\text {hitung }}$ dibandingkan dengan $t_{\text {tabel }}$ dengan $d k=n_{1}+n_{2}-2=74$ pada taraf kepercayaan $\alpha=0,05$ diperoleh $\mathrm{t}_{\text {tabel }}=1,6677$ Ternyata didapat $\mathrm{t}_{\text {hitung }}>\mathrm{t}_{\text {tabel }}$, sehingga hipotesis $\mathrm{H}_{0}: \mu_{1}=\mu_{2}$ ditolak.

Berdasarkan pengujian uji-t diperoleh thitung $=2,3533$ dengan taraf kepercayaan 95\%, sedangkan $t_{\text {tabel }}=1,6677$. Oleh karena itu $t_{\text {hitung }}>t_{\text {tabel }}$, dan hipotesis $\mathrm{H}_{0}: \mu_{1}=\mu_{2}$ ditolak, yang menyatakan "Hasil belajar matematika siswa yang diajar dengan penerapan pembelajaran kooperatif teknik dua tinggal dua tamu lebih baik dari hasil belajar matematika yang diajar dengan metode pembelajaran konvensional pada siswa kelas X SMAN 1 Lembah Gumanti”.

Walau dari uji statistik menunjukan bahwa hipotesis yang penulis ajukan diterima, tetapi apa yang ditemukan dilapangan dalam proses belajar dan pembelajaran teknik dua tinggal dua tamu tidak terlaksana dengan baik. Pada saat pelaksanaan penelitian, penulis mengalami banyak kesulitan pada saat menerapkan pelaksanaan teknik dua tinggal dua tamu, diantaranya saat akan pergi saling bertamu, dimana siswa hanya mencatat apa yang sudah mereka ketahui dalam kelompok lain tetapi mereka tidak memahami apa-apa yang mereka catat. Hal ini menyebabkan hasil belajar siswa masih berada di bawah kriteria ketuntasan maksimum.

Dari hasil analisis data terlihat bahwa nilai rata-rata pada kelas eksperimen adalah 54,789 dan kelas kontrol adalah 44,236. Dilihat dari segi ketuntasan belajar siswa secara individu maka diperoleh pada kelas eksperimen nilai siswa yang diatas atau sama dengan KKM yang diterapkan sekolah 70 adalah 7 orang atau 18,42\% sedangkan kelas kontrol sebanyak 5 orang atau 13,15\%. Jadi, dapat disimpulkan bahwa pada kelas eksperimen siswa yang memperoleh nilai diatas KKM lebih banyak dari pada kelas kontrol. Berdasarkan perhitungan variansi diperoleh variansi kelas eksperimen 18,885 dan kelas kontrol 20,101. Sebelum penelitian kelas $X_{3}$ yang dijadikan kelas eksperimen perhitungan variansi diperoleh hal ini berarti bahwa nilai siswa dikelas eksperimen lebih beragam dari pada kelas kontrol.

\section{KESIMPULAN DAN SARAN}

Dari uraian dan hasil pengujian yang telah dipaparkan pada bab IV di atas diperoleh kesimpulan yaitu hasil belajar matematika siswa yang di ajar dengan penerapan pembelajaran kooperatif teknik dua tinggal dua tamu dengan mengunakan LKS lebih baik dari pada hasil belajar matematika siswa yang di ajar dengan pembelajaran konvensional pada taraf kepercayaan 95\%. Dengan rata-rata hasil belajar matematika siswa pada kelas eksperimen 54,789\% sedangkan pada kelas kontrol rata-rata hasil belajar matematika siswa 44,238\%. 
Dari hasil penelitian dan kesimpulan yang penulis berikan, maka penulis dapat menyarankan halhal sebagai berikut:

1. Untuk dapat meningkatkan hasil belajar yang lebih baik, maka sebaiknya pada tahap pelaksanaan lebih diperbaiki lagi. Orang yang bertamu tidak hanya menerima apa yang didapat dari kelompok yang dikunjungi tapi mereka juga memberi kepada tuan rumah, dan untuk yang tinggal tidak cuma menjelaskan tetapi juga bertanya kepada yang datang. Sehingga dalam kelompok terjadi diskusi secara berulang-ulang sehingga banyak yang dibahas dan saling bertukar pikiran.

2. Karena penelitian ini dilakukan pada siswa kelas X SMAN 1 Lembah Gumanti dengan materi bentuk pangkat dan akar maka penulis berharap juga dapat dikembangkan pada materi lain, tetapi dengan lebih memperhatikan kondisi siswa dan tata cara pelaksanaan.

\section{DAFTAR PUSTAKA}

Djaafar, Tengku Zahara. (2001). Kontribusi Strategi Pembelajaran Terhadap Hasil Belajar. Jakarta: Universitas Negeri Padang.

Ibrahim, Muslimin. (2000). Pembelajaran Kooperatif. Surabaya: UNESA Universitas Press.

Istarani. 2012. 58 Model Pembelajaran Inovatif. Medan : Media Persada

Lie, Anita. (2002). Cooperative Learning (Mempraktikkan Pembelajaran Cooperative Learning di Ruang-Ruang Kelas). Jakarta: Grasindo.

Nazir, M. (2003). Metodologi Penelitian. Jakarta: Ghalia Indonesia.

Suherman, Erman. (2003). Strategi Pembelajaran Matematika Kontemporer. Bandung: JICA.

Sudjana. (2005). Metoda Statistika .Bandung: Tarsito. 